Reynaldo Thompson, Tirtha Mukhopadhyay *

\title{
Projeto Sideral e a música de animismo cósmico
}

Reynaldo Thompson studied architecture at the University of Guanajuato and at the Polytechnic University of Catalonia in Barcelona as well as in University of Texas at Dallas, the latter being where he obtained the Doctoral degree in aesthetic studies focused on Contemporary Art. He has participated in different exhibitions both individual and collective and conducted shows in Mexico and abroad. He served as director of Department of Art and Business of the University of Guanajuato and is currently focused on research art, science and technology in Latin America. <thompson@ugto.mx> ORCID: 0000-0002-9328-1429
Resumo 0 projeto Sideral foi desenvolvido pelos artistas Marcela Armas e Gilberto Esparza, como mais um acréscimo à série de esculturas eletrofônicas expostas por Esparza depois que ele recebeu o Golden Nica de 2015. Em seu esquema básico, o Concepción-Adargas, que é o título do trabalho que emana do Projeto Sideral, usa um meteorito de 3,3 toneladas, que atingiu em 1786 o estado de Chihuahua, México e agora é preservado pelo Instituto de Astronomia da Universidade Nacional Autônoma do México (UNAM). O campo magnético na superfície do meteorito é detectado e traduzido em sons que recriam as harmonias distantes de Buchla, de maneira semelhante à composição Licht de Stockhausen ou às canções contemplativas de Pauline Oliveros, por mais importantes que sejam em aspectos do som, é o companheiro de Armas e Esparza, Daniel Llermaly, que os transforma em termos semelhantes aos da música indígena Tarahumara, uma frequência semelhante conhecida pelos povos da região onde o meteorito atingiu.

Palavras chave Acústico, Eletrofônico, Magnético, Meteorito, Sideral. 
Tirtha Mukhopadhyayis Professor at the Department of Art and Enterprise, Universidad de Guanajuato, Mexico, and Federal Research Fellow at Conacyt, Mexico. He is a transdisciplinary scholar with numerous publications from the Oxford University Press, MIT Press, and Atelier-Etno UISSP-CISENP, Italy, among others. Mukhopadhyay's doctoral dissertation titled Affective States in Art is available as a Proquest-UMI Paperback in Google Books since 2005. He is also Chief Editor of a Scopus indexed interdisciplinary journal called Rupkatha from 2009.<tirha@ugto.mx> ORCID: 0000-0002-2707-930X

\section{Project Sideral and the Music of Cosmic Animism}

Abstract Project Sideral was developed by artists Marcela Armas and Gilberto Esparza, as another addition to a series of extraordinary electrophonic sculptures they exhibited since Esparza's award-winning Golden Nica piece of 2015. In its basic outline, the Conception-Adargas, which is the title of the work emanating out of Project Sideral, uses a 3.3 tons meteor, which impacted the state of Chihuahua, Mexico, and was found in 1786 and then preserved at the 'Astronomy Institute' of the National Autonomous University of Mexico. The magnetic field on the surface of the meteorite is detected and translated into sounds which recreate the far out harmonies of Buchla's dream easel, in modes similar to Stockhausen's Licht, or Pauline Oliveros's contemplative chants, but which more importantly, Armas and Esparza's companion Daniel Llermaly transform in terms of the indigenous Tarahumara music, a similar frequency known to peoples of the region on which the meteorite impacted.

Keywords Acoustic, Electrophonic, Magnetic, Meteorite, Sidereal.

\section{Proyecto Sideral y la musica de animismo cósmico}

Resumen El proyecto Sideral fue desarrollado por los artistas Marcela Armas y Gilberto Esparza, como otra adición de la extraordinaria serie de esculturas electrofónicas que ha exhibido desde que Esparza fue galardonado con el Golden Nica de 2015. En su esquema básico, la Concepción-Adargas, que es el título del trabajo que emana del Proyecto Sideral, utiliza un meteorito de 3.3 toneladas, que impactó en 1786 en el estado de Chihuahua, México y ahora preservado por el 'Instituto de Astronomía' de la Universidad Nacional Autónoma de México (UNAM). El campo magnético en la superficie del meteorito se detecta y se traduce en sonidos que recrean las armonías lejanas de Buchla, en modos similares a la composición Licht de Stockhausen, o a los cantos contemplativos de Pauline Oliveros, sin embargo lo importante en aspectos de sonido, es el compañero de Armas y Esparza, Daniel Llermaly quien los transforma en términos similares a los de la música indígena tarahumara, una frecuencia similar conocida por los pueblos de la región en donde impactó el meteorito.

Palabras clave Acústico, Electrofonico, Mágnetico, Meteorito, Sideral. 


\section{Introduction}

Un coup de dés jamais n'abolira le hasard

(A throw of the dice will never abolish chance)

- Stéphane Mallarmé

Many syntheses harmonize into the sidereal music of La Concepción- Adargas, or (henceforth) the 'Conception-Adargas' (in English), an installation which retro-feeds basic elements of electromagnetic wave technology into art. Conception-Adargas is an electro-kinetic installation with a meteorite whose ferro-magnetic activity is transformed into music. And it is the child of Project Sideral, an extraordinary anti-disciplinary quest into the sidereality of things.

But this time Mexico's celebrated artists, Marcela Armas and Gilberto Esparza, along with companion techie Daniel Leido, and their composer friend Daniel Llermaly, dig through the Cenozoic origins of music in their project Sideral - 'sideral' being the Spanish word for 'sidereal', and reminiscent of Paul's eschatological denomination of a sidereal body, a resurrection. Project Sideral sought to transform all vitalistic field properties of celestial objects by means of digital synths into aural dimensions and effects.

So, what is project Sideral?

Armas and Esparza's project concretizes Buchla's search for modular electrophonics in a tangible extraterrestrial object - namely, a paleomagnetic meteor that impacted earth on 26th April 1786, not unlike the Chicxulub meteor that hit Yucatan peninsula some 300 million years ago, but this time within scalable limits of the human imagination. This meteorite was found at the Adargas mountain range in the state of Chihuahua bordering Mexico and the United States, and one of the most transitional territorial sites of human history. La Concepcion-Adargas derives its name from Adargas (the mountain range where it was found) and the Hacienda La Concepcion where it was preserved, 'hacienda' referring to a house or preservatory in Spanish. Thus, the naming of the sound installation combines place references, just as it carries all its meaning in information from its origins in an unknown intra-solar niche.

Armas and Esparza creates an almost spiritualist icon out of this object from space. In its basic structure Sideral deals with this 3.3 tons meteor, which impacted earth in 1786. The meteor was preserved at the Astronomy Institute of the National Autonomous University of Mexico. The magnetic field on the surface of the meteorite is detected and translated into sounds which recreate the far-out harmonies of Buchla's dream easel, in modes similar to Stockhausen's Licht, or Pauline Oliveros's contemplative chants called Accordion, but which more importantly, Armas and Esparza's companion Daniel Llermaly transform in terms of the indigenous Tarahumara music, a very similar pure frequency known to peoples of the region on which the meteorite impacted in an undescribable past ${ }^{1}$.

No description could even begin to do justice to the profound apocalypse of Sideral's art product, the Conception-Adargas. 


\section{Project Sideral and the Formation of the Conception-Adargas}

Sideral prototype Conception-Adargas was exhibited for the first time in the former Templo Church of Santa Teresa, now a Ex-Teresa Arte Actual, a contemporary art space in Mexico City, as part of a collaborative exhibition of thirteen German and Mexican contemporary artists, and sponsored jointly by the Goethe-Institute Mexico and the Singuhr-Project Museum Berlin. The event was hosted under the German-Mexico Dual Year celebrations. Curator Carsten Seiffarth invited Marcela Armas and Gilberto Esparza to exhibit the project Sideral, as a rendition of a paranormal, explorative piece on sonic art, and under the title-rubric of 'Between Limits'. An event organized for the first time in the last week of August 2016, was in fact an accumulative simulation of elements to which Marcela Armas, Gilberto Esparza and their Chilean born musician-colleague Daniel Llermaly had brought in their minds, to converge. Thus materialized Sideral's primary exhibit, the Conception-Adargas, a sidereal electrophonic sculpture, that used technology to synth pre-historical sonic modes. Conception-Adargas the title refers to the name of the village, eponymously mysterious to say the least, of the Raramuri peoples of Chihuahua, and thus in its execution the installation also appropriated a cultural space that was subjected to its technological interventions ${ }^{2}$.

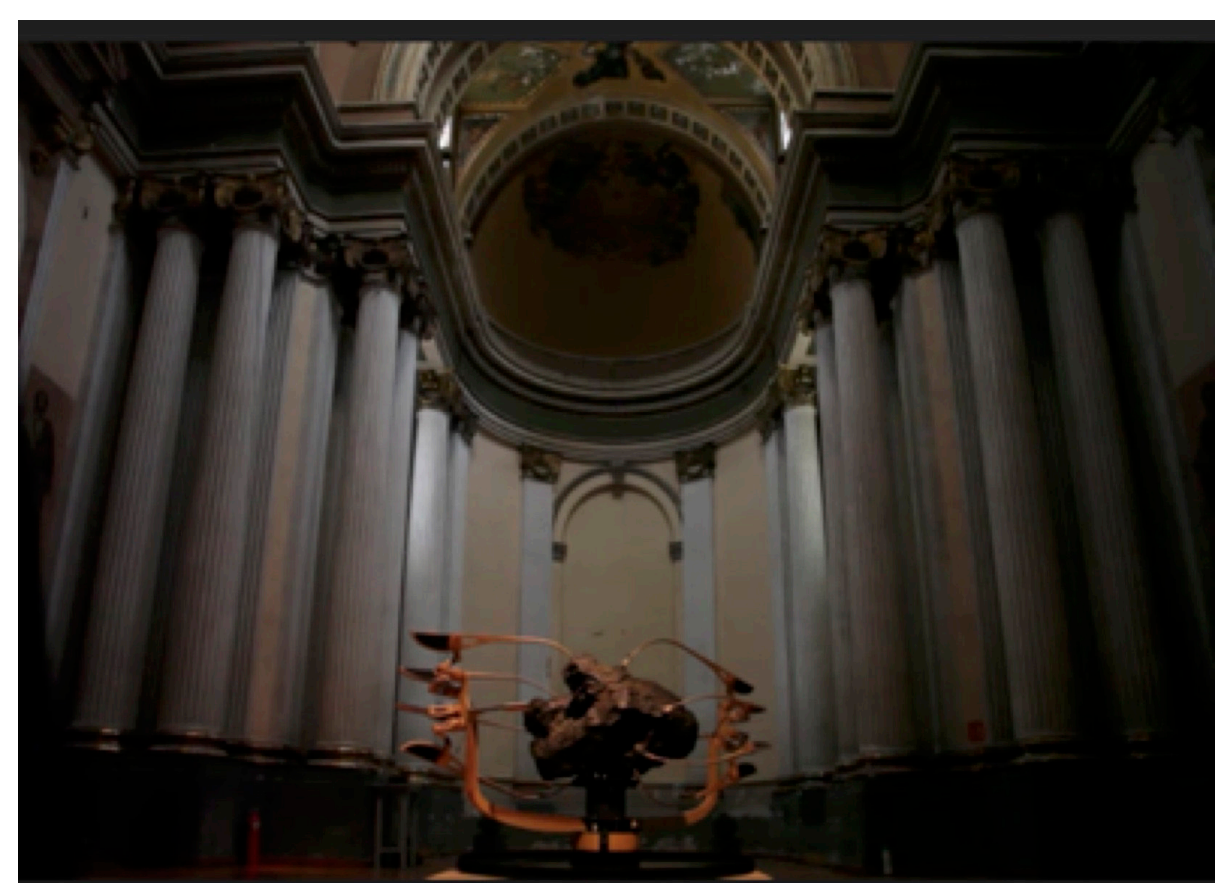

Fig 1. Conception-Adargas as it appears as an exhibit 'Between Limits' held in 2016-2017 
Seiffarth, the curator of the German-Mexico collaborative exhibition invited Armas and her colleagues as part of this festival of sonic arts in which the basic drive of artists was primarily to explore the limits of music, especially its elemental wave formats - a practice which seeks to transform magnetic impulses into harmonies, one which was already part of the spectrum of such arts since the Buchla music easel helped initiate its analog versions. Stockhausen, and Pauline Oliveros could be considered as forerunners who created windows of similar sonic perceptions. Daniel Llermaly's take on Armas' magnetic readings and Esparza's near eccentric combinations of protocols, complexifies Conception-Adargas into one of the most profound electrophonic sculptures of our times.

\section{Genesis and Trajectory of the Conceptiom-Adargas}

This collection of meteorites at the Astronomy Institute of UNAM was originally discovered in Adargas mountains, Chihuahua and preserved at a property called the Hacienda La Concepcion, which, as we said, provided the title of the work. Armas and Esparza's collaborators at the Astronomy Institute pointed out how meteorites were, in our perspective, almost like animistic entities, a fact which lead Armas and Esparza to celebrate as the 3.3 tons meteor seemed to burst into explosive magnetic activity once the sensors were interactively guided along its surface. Esparza along with Diego Leido, a friend and colleague helped design a mechatronic mantel, all around the entire 3.3 tons meteorite. The instrument consists of 8 arms fitted with compass sensors that could detect the field on the surface of the meteorite along its isomorphically oriented $\mathrm{X}, \mathrm{Y}$ and $\mathrm{Z}$ axes. In accordance with Maxwell's magnetic field displacement activity, the sensors were equipped to sensitize to at least three kinds of fields on the Cartesian frame for the subsequent musical transformations.

The fact that the German-Mexican dual year exhibition would result in bringing a meteor from Adargas Chihuahua, then at the Astronomy Institute of the UNAM, to the Ex-Teresa Museum is interesting. The Ex Teresa Museum's cupola was especially suited for acoustic sensitivity, which was more than a strange coincidence for the project and seemed to harmonize a celestial object with the secret mysteries of a sidereally evocative structure as that of the old religious edifice at the heart of Mexico City. As the installation appears in its final moment it therefore resembles an alien device, including a meteor at its center, and digital sensors navigating its surface for magnetic signals whose origins are embedded deep in time.

After your text edit has been completed, the paper will be ready for the template. You can duplicate the template file by using the Save As command, and the naming convention prescribed for the name of your paper. In this newly created file, highlight all of the contents and import your prepared text file. You are now ready to style your paper. 


\section{Berlin-Treptow and FAB LAB}

Part of the impetus came from Armas and Esparza's visualization of the Conception-Adargas as a new kind of metallurgic hybrid. Armas initial studies with the properties of meteor were complemented with their visit to the Observatory Archenhold Sternwerte at Berlin. By some quirk of fate a meteor that impacted on the Devil's Canyon range in Arizona came to be preserved at the Archenhold Sternwerte Observatory center at Berlin-Treptow. Armas and Esparza utilized the opportunity of working at the observatory with the machine in order to generate frequencies for the sound composition, and of studying and eventually evolving a model prototype for the Ex Teresa exhibition of 2016.

For Armas and Esparza the exposure at the Berlin Observatory initiated the process of representations of the celestial properties and behaviors for a meteor inclusive piece. This was achieved in Berlin before the maturation of the Conception-Adargas piece for the August of 2016. Indeed, the evolution of the second phase of Sideral starts more radically out of Armas and Esparza's work in the FAB LAB facility at Berlin, where the whole team got things rolling for the project. They also eventually finished developing the instruments at the FAB LAB studio (a media lab facility) at Berlin.

In FAB LAB they were working with a meteor from Devil's Canyon Arizona, retained at the Archenhold Sternwerte Observatory, which was used to generate a kind of prototype. Once the usable sensors were in place, the target was to adapt them for the octopedic navigator which could consequently move by gently rolling across the surface: this was designed with a set of rotators that were electrically guided by the signals generated from the meteor surface. This was done out of simple lightweight material. The lightweight wooden arms of the Sideral sculpture was generated by a software-generated drawing for a model. Each arm was carefully crafted and installed delicately from a central hub over the center of the meteorite, and the rollers of the arms placed along the uneven surface for sensitizing contact and the subsequent generation of data-sets for processing.

The passage of sensors thus generates a data stream, a basic interpretive mechanism that Armas and her friends exploited - but this time perhaps the end need not be visual. Of course, there was precedence in Esparza's Biosonot robots and the exotic Plantas Autofotositeticas (2012), which was awarded the Golden Nica in 2015. Hybridism was carried over from the technical expertise of the Plantas Autofotosinteticas which they developed in San Miguel de Allende, Mexico. Later experiments in data collection for the Sideral project was instrumentalized by Armas, Esparza and Flores in their consistent effort to recuperate and streamline the data for further transformations, and the ultimate stage, concerned with sound extraction was not getting to be difficult. The realization of sonic elements in a digital process of data collection and recuperation, had emerged as the signature style for Esparza in the intervening years. 
Fig 3. Buinding of a sensorial mantel that captures and replicates harmonies

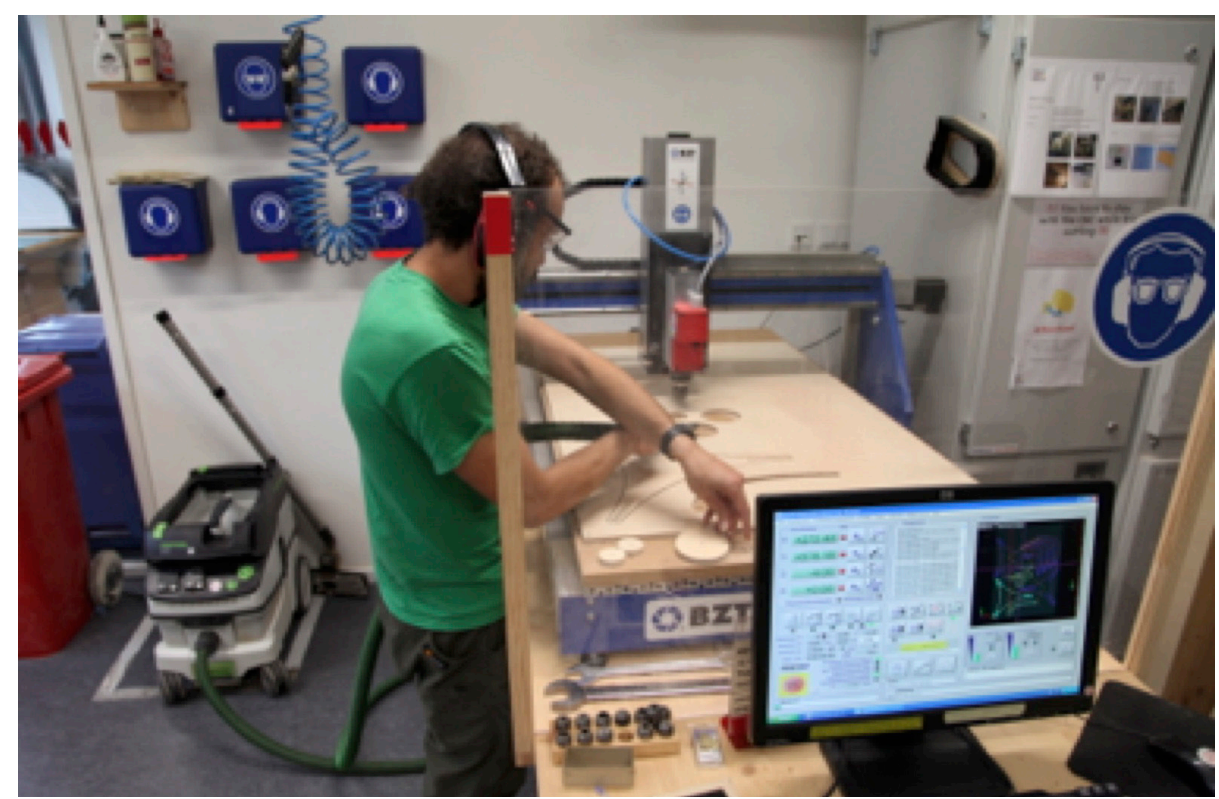

FAB LAB became the space for executing a perfect electromechanical model that would serve as an extractor mantle for the meteor. Programming required for this step was again not complex, as the rotator mantel had to adjust itself to the rollers that traversed the meteor's body. The aesthetics of the mantel is again reminiscent of an object from space, like an R2D2 contraption. There is that still, subdued humor in Conception-Adargas that marks every Armas and Esparza project.

In the other phase at the Fonoteca Nacional Armas and Esparza did part of the research on music. They listened to and appropriated the field recordings of the object from the region: this allowed them to evoke a sense of place for the sonic manipulations. The meteorite became a sort of orchestra director, which depending on the information that it transmitted defined the path for the sonic atmosphere of the piece. The sound is practically never repeated because of the differently oriented readings of the fields emitted around the stone. There is no defined map of the magnetic fields generated by the sensors and therefore, the patterns keep changing stochastically in each reading of the surface. A random combination of data from the sensors is sent to a synthesizer that controls different parameters for the creation of symphony. In this sense therefore, the meteorites turn into an 'ambassador' of other worlds as Armas and Esparza like to call it. The kinetic installation offers a sensory version of the meteorite and therefore represent how such "bodies" appear on the other side of life. 


\section{The British Sojourn of Conception-Adargas}

The prototype for Sideral constructed in Berlin FAB LAB had a lucky spree of exposures including one in Glasgow. Armas and Esparza exhibited at Glasgow with a meteorite brought from London (Natural History Museum), one named Box Hole and weighing $80 \mathrm{~kg}$. This meteorite originally fell in Australia, and was used by Armas and Esparza to recreate another installation at Glasgow. The piece was assembled at the behest of an invitation from Cathie Boyd, Director of Cryptic's Sonica Festival (Cryptic is a Glasgow based internationally-renowned producing art house), for the annual electronic music festival at Glasgow. Again, the prototype remains the same as the installation tried to recreate the sounds of space from a different location.

\section{Electrophonic Compositions of Sideral}

One of Sideral's basic attempts in the Ex-Teresa installation was therefore to recuperate the sonic atmospheres around the Adargas mountains and the Hacienda La Concepcion, a region famous for its pre-history and the evolution of the Uto-Aztecan family of peoples. Indeed, music is also of the essence in this project. The exhibition of Conception-Adargas at Ex-Teresa involved the production of sonic harmonies in an ambience especially intensified by its acoustic multiplications.

The sublime isolation of interstellar sound frequencies, at its purer, elemental level became something of a sublime fad with composers like John Cage and then Karlheinz Stockhausen, and not to mention the enchanting sonic harmonization of Pauline Oliveros ${ }^{5}$. The extension of the science of music to its aesthetic limits was not something that Armas and her colleagues had been obsessing with at first. But the presence and harmonic syntheses achieved by Daniel Llermaly takes this stellar hybrid to another dimension and provokes a continued dialogue with the most beautiful musical compositions of the last century, from Cage to Stockhausen, and from Pauline Oliveros to contemporary electronics composers of our times. On a very broad stage, team Sideral proposes a link between the sonic purities of non-literate, pre-historic cultures and the scientific singularities anticipated by the avant-garde, in the rediscovery of the song of the earth and the song of outer space and the legacies it leaves forward for the human processor.

In Armas humble words, they "were in search of the Paleomagnetism of earth" and it was a discovery none-the-less. Music predates human existence, and its proof lies in the Sideral magnetism that carries the image of sound in its progression. A pre-cosmological time frame requires the birth of sounds in the moments posterior to the moments of the hypothesized Big Bang and the latter expansion of the universe. 
Paleohistory was intrinsic to the installation. Daniel Llermaly was very important for this type of research. The association of Armas and Esparza with Llermaly was long, as they were interested in Llermaly's work when extracting musical notes from hydrophonic processes like the breaking of glaciers, a theme which LLermaly had been working on. Llermaly was already conceiving extraordinarily large geological ideas of sounds. What are the possibilities of detecting or creating music in instruments that detected them in bacteria for example? For four years Esparza and Llermaly were working on bacterial music. Llermaly interpreted the information very successfully in recent years, especially in the the glaciers project.

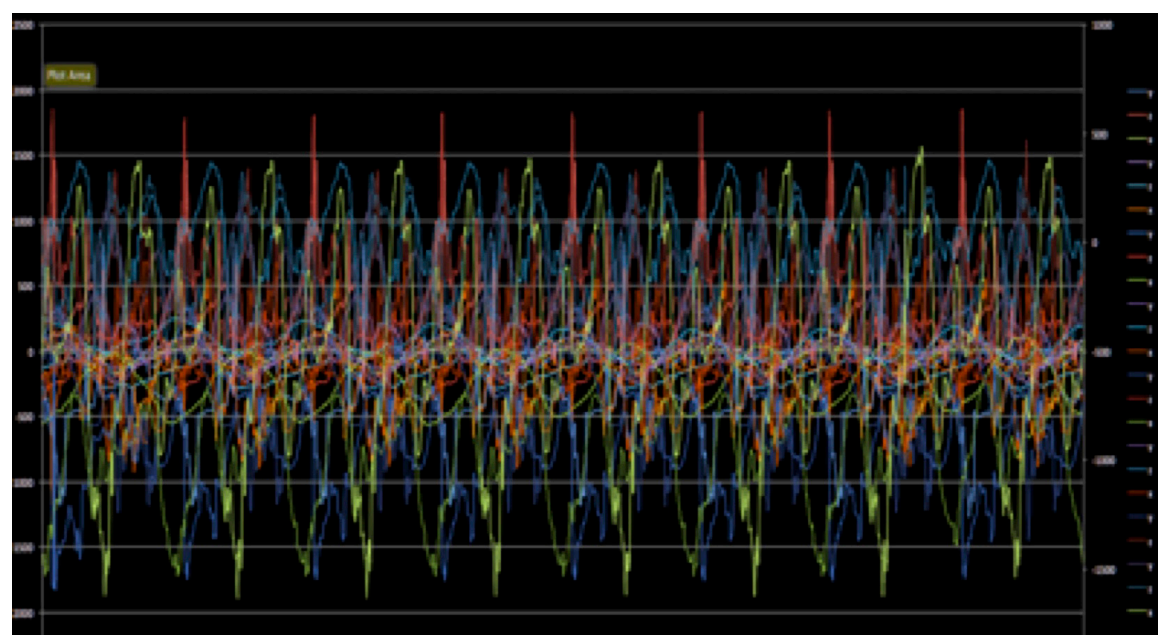

Fig 24. A radiograph illustrating timber and harmonic synchronization of rarámuri

For Sideral a quadrophonic instrument generates the sonic waves in accordance with a program written on PUREDATA, a free software and an essentially simple mixing tool. Armas, Esparza, Llermaly tried to perceive and translate this complexity of meteoric magnetism into harmonic equilibrations. We know it is information but the sound is a vehicle, and as we think of space we also see how all sounds are created with reference to a place. Localization seemed important for the trio. They were interested in the sounds that were also intrinsic to sounds of communities. In digitally trying to find sonic equivalents Armas and her colleagues were re-creating the opportunity for the apparently inert stellar visitants to communicate with the communities of Adargas, Chihuahua. Their concern was to digitally create the sounds of these places. "We just wanted the symphony to recreate the atmosphere of the phenomenon", says Armas ${ }^{6}$. It is a human reference for an extraterrestrial phenomenon. "We are talking about millions of years. Earth is a complex organism - populated by singular living forms. We are part of this living system" ${ }^{7}$, and the music connects these levels in an entropic continuity. 
Llermaly was saying the same thing in his own words but perhaps he recreates a direct feeling for the Raramuri ritual music. Llermaly, makes us aware that the electrophonic note, so admirably identified and transmogrified by Stockhausen among others, has its reference in things bound to time and location, and could be derived from information or raw data. The sound of Sideral, born out of stellar reactivity, penetrates with a single harmonic note through the night, just as Stockhausen's vibrations simulate the journey of light through a presumably invisible space of being. The Raramuri music, now rendered in notes, derived from celestial music has a dialogic impact on matter from earth. The vibe grips us, as in Llermaly's rendition of Conception-Adargas's inalienable notes, with the fear of some infinite process in nature. It is this dimension that Conception-Adargas symbolizes and translates into sound. In a sense project Sideral connects our perception with these animistic time frames within the universe, through layers of being and through the fear and the glory of it all.

1 Sitsky, Larry. Music of the Twentieth-Century Avant-Garde: A Biocritical Sourcebook: A Biocritical Sourcebook. ABC-CLIO, 2002.Taylor, Timothy D. "The gendered construction of the musical self: The music of Pauline Oliveros." The Musical Quarterly 77, no. 3 (1993): 385-396.

2 Ochoa-Zezzatti, Alberto, Julio Ponce, Arturo Hernández, Sandra Bustillos, Francisco Ornelas, and Consuelo Pequeño. "Traditional Rarámuri Songs used by a Recommender System to a Web Radio." Special issue: Natural Language Processing and its Applications: 243.

3 Trías, Eugenio. "El canto de las sirenas." Barcelona, Galaxia Gutenberg (2010).

4 Tirtha Mukhopadhyay and Reynaldo Thompson. EcoCybers: The Story of Digital Art in San Miguel De Allende. http://www.idmaajournal. org/2015/11/ecocybers-the-story-of-digital-art-in-san-miguel-de-allende/ retrieved 5th January 2020

5 Szanto, Ted. "Extended vocal techniques." Journal of New Music Research 6, no. 3-4 (1977): 113-115.

6 Marcela, Armas. Tatiana Cuevas, Matthew Hall, Jens Hauser, Karla Jasso, Jose-Carlos Mariategui. Jessica Riskin. Lima: Peru. Espacio Fundación Telefónica. Also based on personal interview dated 3rd January 2018. 7 Marcela, Armas. Tatiana Cuevas, Matthew Hall, Jens Hauser, Karla Jasso, Jose-Carlos Mariategui. Jessica Riskin. Lima: Peru. Espacio Fundación Telefónica. Also based on personal interview dated 3rd January 2018. 